\title{
Corporate Financial Restatements From 1995 Through 2020
}

\author{
Mary Fischer \\ The University of Texas at Tyler \\ David Kyle Shumburger \\ Ernst \& Young LLP
}

This study investigates corporate financial restatements in the United States from the pre-SOXs period (1995) to the pandemic period (2020) and finds issues of interest to policy makers, auditors, and corporate management. In the early years of the study, fewer than 50 restatements are of record. The 2005 year began a period of increasing filings due to the Sarbanes-Oxley Act with the annual restatements reaching almost 2,000 that slowly declines to only several hundred in 2020. A major portion of the restatements result from interpretation and application of Generally Accepted Accounting Principles (GAAP) accounting rules by publicly owned firms engaged in mechanical, transportation, finance, and service activities. Although the number of restatements decline, the justification for the restatements remain the result of inappropriate recognition or incorrect interpretation of new accounting guidance. Fraud and clerical issues continue to be an insignificant cause for a restatement.

Keywords: restatement causes, frequencies, special issues, industry concentration

\section{INTRODUCTION}

Financial restatements spanning 1995 through 2020 provide the basis for this analysis of financial restatement issues, frequencies, special issues, and industry concentration. The analysis reviews 18,797 financial restatements published from March 1995 to October 2020 issued by 10,581 firms over the 25-year period. The number of annual restatements range from 10 in 1995, to a peak of 1935 in 2006, and diminishes to 300 restatements in 2020 (see TABLE 1).

The federal securities laws require publicly reporting companies to disclose a comprehensive overview of the company's business and financial condition and include audited financial statements (SEC, 2020). A financial restatement is a formal revision and audit of a previously issued audited annual financial statement that was found to include inappropriate accounting rule compliance of new reporting standards, and unintentional (or intentional) errors/violation of GAAP. Companies with strong internal control systems and organizational ethics are less likely to issue financial statement that include reporting errors (Lin et al., 2015).

Financial statement audits are performed by external auditors who respond to the audit committee of the company under audit (Ghosh et al., 2010). The 2002 year began a period of increasing restatements due to Congress enacting the Sarbanes-Oxley Act (SOX) of 2002 also known as the Corporate and Auditing Accountability, Responsibility and Transparency Act. SOX set new and expanded reporting requirements 
for all US public companies, management, and public accounting firms (United States, 2002). Congress adopted the SOX Act in response to a series of scandals perpetrated by corporate giants such as Enron Corp. and WorldCom Inc. that were responsible for bankruptcies and permanent financial ruin for many investors. Politicians in Congress claimed SOX to be the most sweeping reform since the Depression-era securities laws (Cunningham, 2002).

TABLE 1

U. S. CORPORATE FINANCIAL STATEMENT RESTATEMENTS 1995 THROUGH 2020

\begin{tabular}{|c|c|c|c|c|}
\hline Year & $\begin{array}{c}\text { Number of } \\
\text { Restatements }\end{array}$ & $\begin{array}{l}\text { Restatements with Audit } \\
\text { Issues }\end{array}$ & $\begin{array}{l}\text { Restatements } \\
\text { Containing } 2 \\
\text { Issues }\end{array}$ & $\begin{array}{c}\text { Restatements } \\
\text { Containing } 3 \\
\text { Issues }\end{array}$ \\
\hline 2020 & 300 & 339 & 39 & - \\
\hline 2019 & 498 & 563 & 61 & 4 \\
\hline 2018 & 566 & 647 & 79 & 2 \\
\hline 2017 & 611 & 694 & 75 & 8 \\
\hline 2016 & 714 & 805 & 87 & 4 \\
\hline 2015 & 794 & 899 & 101 & 4 \\
\hline 2014 & 885 & 1,011 & 120 & 6 \\
\hline 2013 & 888 & 1,009 & 119 & 2 \\
\hline 2012 & 871 & 959 & 84 & 4 \\
\hline 2011 & 856 & 947 & 87 & 4 \\
\hline 2010 & 875 & 920 & 39 & 6 \\
\hline 2009 & 842 & 900 & 54 & 4 \\
\hline 2008 & 990 & 1,070 & 70 & 10 \\
\hline 2007 & 1,363 & 1,427 & 58 & 6 \\
\hline 2006 & 1,935 & 2,091 & 146 & 10 \\
\hline 2005 & 1,683 & 1,894 & 185 & 26 \\
\hline 2004 & 995 & 1,097 & 92 & 10 \\
\hline 2003 & 876 & 933 & 53 & 4 \\
\hline 2002 & 739 & 795 & 52 & 4 \\
\hline 2001 & 642 & 670 & 26 & 2 \\
\hline 2000 & 551 & 569 & 14 & 4 \\
\hline 1999 & 137 & 141 & 4 & - \\
\hline 1998 & 88 & 95 & 7 & - \\
\hline 1997 & 64 & 67 & 3 & - \\
\hline 1996 & 24 & 27 & 3 & - \\
\hline 1995 & 10 & 10 & - & - \\
\hline Totals & 18,797 & 20,579 & 1,658 & 124 \\
\hline
\end{tabular}

Source: Author created using Audit Analytic date (2020).

Corporate financial reporting quality is an area of distinct relationships between auditors, regulators, and corporate management. Regulators aim to provide transparency to the entire public and corporate stakeholders both internal and external. Corporate managers' interest is to provide maximum benefit to a small group of internal stakeholders and its shareholders. There is an interest gap between regulators and corporate managers that provides a challenge for the public interest. To resolve this challenge, external auditors are tasked with bridging that gap as they balance the transparency requirements of the regulators with the maintenance of the client relationship. The external auditor is responsible for auditing the financial statements of their corporate client and expressing an opinion over corporate management's assertion that 
the financials have been presented fairly and in accordance with Generally Accepted Accounting Principles (GAAP). When auditors discover material misrepresentations that are either due to unintentional errors, misinterpretation of accounting principles, intentional acts of fraud, or other improprieties, they report the issue to the audit committee of the corporate client. When the issues are discovered, corporate management is required to restate the impacted periods' financial statements with the appropriate corrections (Alali \& Wang, 2017). These restated financial reports are known as restatements.

\section{DATA SOURCE}

This analysis uses restatement data from the Audit and Compliance Module of Audit Analytics (www.dataanalytics.com), a research database specializing in tracking detailed information of financial statements restatements, and company audit information. Audit Analytics collects restatement data covering all SEC registrants from various SEC filings and press releases. Applying data analytic procedures to the total population provides observable trends detailing the timing, and volume of restatements during a given period.

\section{RESTATEMENT TRENDS}

Leading up to the early 2000's, restatements rose increasingly from 1995 through the years 1996 to 1999 by $140 \%, 168 \%, 38 \%$ and $56 \%$, respectively. Although the percentages are large, they represent a small number of restatements with 10 in 1995 representing the lowest to 137 in 1999 representing the highest for the period. Concluding the 1990 period was the increase of 414 restatements in 2000 totaling 551 that is a $302 \%$ increase from the number of restatements issued in 1999 . The frequency of restatements rose incrementally during the years 2001 to 2004 by 17\%, 15\%, 19\% and 14\%, respectively. Although the percentages continue to be small, they represent a relatively large number of restatements with 551 in 2000 representing the lowest number and 995 in 2004 representing the highest number for the period. More noticeable is the increase of 688 restatements in 2005 for a total of 1,683 that is a $69 \%$ increase over the 2004 restatements. The 2005 restatements represent a $66 \%$ greater than the increase realized in 2000 . The number of restatements peaked in 2006 with a total of 1,935 restatements that is a $15 \%$ increase from 2005. Over the period of 2007 to 2009, the number of restatements decreased by $30 \%, 27 \%$ and $15 \%$, respectively. These decreases signal a significant financial statement reporting improvement during the period. Although the restatements decreased, the data represents a large number of restatements that exceed those realized during the years from 1995 to 2002. From 2010 to 2014, the number of restatements was consistent before ultimately diminishing during the years from 2015 to 2020.

Prior to 2000, restatements are rather non-existent in comparison to the 2000's. Noticeable is the restatement increase that occurred in 2000 with a large increase of restatements from 2001 through 2004, together with the increase and peak number of restatements occurring in 2006. Following the peak in 2006, another change in the number of restatements occurs over the years subsequent to 2007 during the U.S. economic downturn. Following the 2007 peak, the number of restatements never declines to the number of restatements issued during the mid and late 1990's. Restatement data over the 25 years found in TABLE 1 details the occurrence of restatements for each year but does not disclose the causes for the restatements. The following discussion presents an analysis of the underlying restatement audit issues during the 25-years of this study.

\section{AUDIT ISSUES AND TRENDS}

Understanding the overall trend of restatements requires an investigation into the audit issues related to restatements. Audit Analytics' data file classifies audit issues related to restatements under four broad categories of audit issues: (1) accounting rule (GAAP/FASB) application failures; (2) financial fraud, irregularities and misrepresentations; (3) clerical - accounting and clerical applications; and (4) other significant issues (IVES Group Inc., 2020). Audit issues relative to total restatements are displayed in 
TABLE 2. The following discussion is a summarization of what causes are included in each of the four categories of audit issues.

Accounting issues such as the accounting rules (GAAP/FASB) and application failures are audit issues that refer to restatements that occur due to accounting rule changes and errors that result in misapplication of GAAP rules or provisions established by the Financial Accounting Standards Board (FASB). These issues indicate an absence of intent on the part of those responsible for misapplications and are referred to as accounting (Lin et al., 2015, 20).

TABLE 2

\section{U.S. CORPORATE FINANCIAL STATEMENT RESTATEMENTS 1995 THROUGH 2020 WITH} BASIS FOR THE RESTATEMENT

\begin{tabular}{|c|c|c|c|c|c|}
\hline Year & $\begin{array}{c}\text { Number of } \\
\text { Restatements }\end{array}$ & $\begin{array}{c}\text { Restatements } \\
\text { based on } \\
\text { Accounting } \\
\text { Issues } \\
\end{array}$ & $\begin{array}{c}\text { Restatements } \\
\text { based on } \\
\text { Fraud Issues } \\
\end{array}$ & $\begin{array}{c}\text { Restatements } \\
\text { based on Clerical } \\
\text { Issues } \\
\end{array}$ & $\begin{array}{c}\text { Restatements } \\
\text { based on Other } \\
\text { Issues } \\
\end{array}$ \\
\hline 2020 & 300 & 287 & 7 & 7 & 38 \\
\hline 2019 & 498 & 487 & 4 & 9 & 63 \\
\hline 2018 & 566 & 554 & 7 & 7 & 79 \\
\hline 2017 & 611 & 602 & 10 & 3 & 79 \\
\hline 2016 & 714 & 698 & 12 & 8 & 87 \\
\hline 2015 & 794 & 772 & 17 & 8 & 102 \\
\hline 2014 & 885 & 870 & 11 & 12 & 118 \\
\hline 2013 & 888 & 870 & 7 & 13 & 119 \\
\hline 2012 & 871 & 845 & 13 & 15 & 86 \\
\hline 2011 & 856 & 811 & 13 & 39 & 84 \\
\hline 2010 & 875 & 835 & 6 & 43 & 36 \\
\hline 2009 & 842 & 785 & 10 & 55 & 50 \\
\hline 2008 & 990 & 923 & 11 & 70 & 66 \\
\hline 2007 & 1,363 & 1,304 & 12 & 63 & 48 \\
\hline 2006 & 1,935 & 1,873 & 19 & 48 & 151 \\
\hline 2005 & 1,683 & 1,591 & 31 & 81 & 191 \\
\hline 2004 & 995 & 923 & 21 & 69 & 84 \\
\hline 2003 & 876 & 826 & 14 & 41 & 52 \\
\hline 2002 & 739 & 674 & 30 & 45 & 46 \\
\hline 2001 & 642 & 613 & 15 & 18 & 24 \\
\hline 2000 & 551 & 527 & 16 & 13 & 13 \\
\hline 1999 & 137 & 130 & 7 & - & 4 \\
\hline 1998 & 88 & 82 & 6 & - & 7 \\
\hline 1997 & 64 & 56 & 8 & - & 3 \\
\hline 1996 & 24 & 21 & 3 & - & 3 \\
\hline 1995 & 10 & 8 & 2 & - & - \\
\hline Totals & 18,797 & 17,967 & 312 & 667 & 1,633 \\
\hline
\end{tabular}

Source: Author created using Audit Analytic data (2021). 
Fraud issues such as financial, irregularities and misrepresentations are audit issues that refer to restatements that occur due to misinterpretation of GAAP rules. These issues indicate a presence of intent on the part of those responsible for the misinterpretations and are referred to as fraud (Lin et al., 2015, 21).

Clerical issues like errors of accounting and clerical applications are audit issues that refer to restatements that occur due to mistakes caused by factors such as insufficient accounting knowledge, errors in judgement, or misinterpretation of facts. These issues indicate an absence of intent on the part of those responsible for such errors and are referred to as clerical (Lin et al., 2015, 21).

Concerns resembling other significant issues are audit issues that refer to restatements that occur due to accounting changes or other disclosure control weaknesses, such as changes from GAAP to International Financial Reporting Standards (IFRS) or internal control weaknesses. These issues typically indicate an absence of intent and are referred to as other issues (Lin et al., 2015, 21).

Analyzing audit issue trends provides a more accurate understanding of restatement over time. Analyzing an overall trend composed of all audit issues only allows a general understanding of the financial restatements as it only answers whether financial restatements are increasing or decreasing. Observation of the underlying audit issues related to restatements allows a better understanding as to whether SEC registrants are improving in any particular audit issue area. Although the overall trend might depict restatements have decreased for a certain period, analyzing the individual audit issues for that period can discern which audit issues are increasing or decreasing. If clerical issues decreased but are offset by increased fraud issues, or vice versa; or, if all accounting issues effectively decreased to an immaterial amount while all other issues increased materially, the aggregate total of restatement does not change. Only further analysis of the individual issues can provide information concerning these types of assertions and changes (AuditAnalytics, 2020).

\section{Accounting Issues}

Restatements climbed from 1995 through 1997 by $163 \%$ and 168\%, respectively, and then began increasing steadily for the years 1998 and 1999 by $38 \%$ and 56\%, respectively. During this period, these large percentages represented a small number of restatements with 8 in 1995 representing the lowest and 130 in 1999 representing the highest number of restatements during the period. Beginning in 2000 there is an increase of 397 restatements, with a total of 527 that is a 305\% increase from 1999. From 2001 through 2004 , the frequency of restatements rose incrementally $16 \%, 10 \%, 23 \%$ and $12 \%$, respectively. During this period, these small percentages represented a large number of restatements with 613 in 2001 representing the lowest number of restatements and 923 in 2004 representing the highest number of restatements for the period. A significant increase of 668 restatements occurred in 2005 with a total of 1,591, a $72 \%$ increase from 2004. The number of restatements increased again in 2006 with a total of 1,873 restatements that is the largest number of restatements during this 25-year study. From 2007 through 2009, the number of restatements decreased by $30 \%, 29 \%$ and $15 \%$, respectively. These declines signal a significant improvement in financial reporting during the period. It should be noted that these decreased numbers of restatement still represent large numbers that exceed the restatements issued during the years from 1995 to 2002. The number of restatements grew again in 2010; however, by only $6 \%$. After 2010, the number of restatements begin to decrease by small percentages over the next decade until 2020.

The most concerning observation is the sharp increase that occurred in 2005 through 2007. Given that accounting issues are the primary factor for the issuance of a financial statement restatement (see TABLE 2), a correlation between the number of restatements and those based on accounting issues as displayed in FIGURE 1 that indicates a correlation between total audit issues and the overall accounting issues during this study's 25-year period. 
FIGURE 1

OVERALL AUDIT ISSUES FOR THE PERIOD 1995 TO 2020 TOGETHER WITH SPECIFIC AUDIT ISSUES

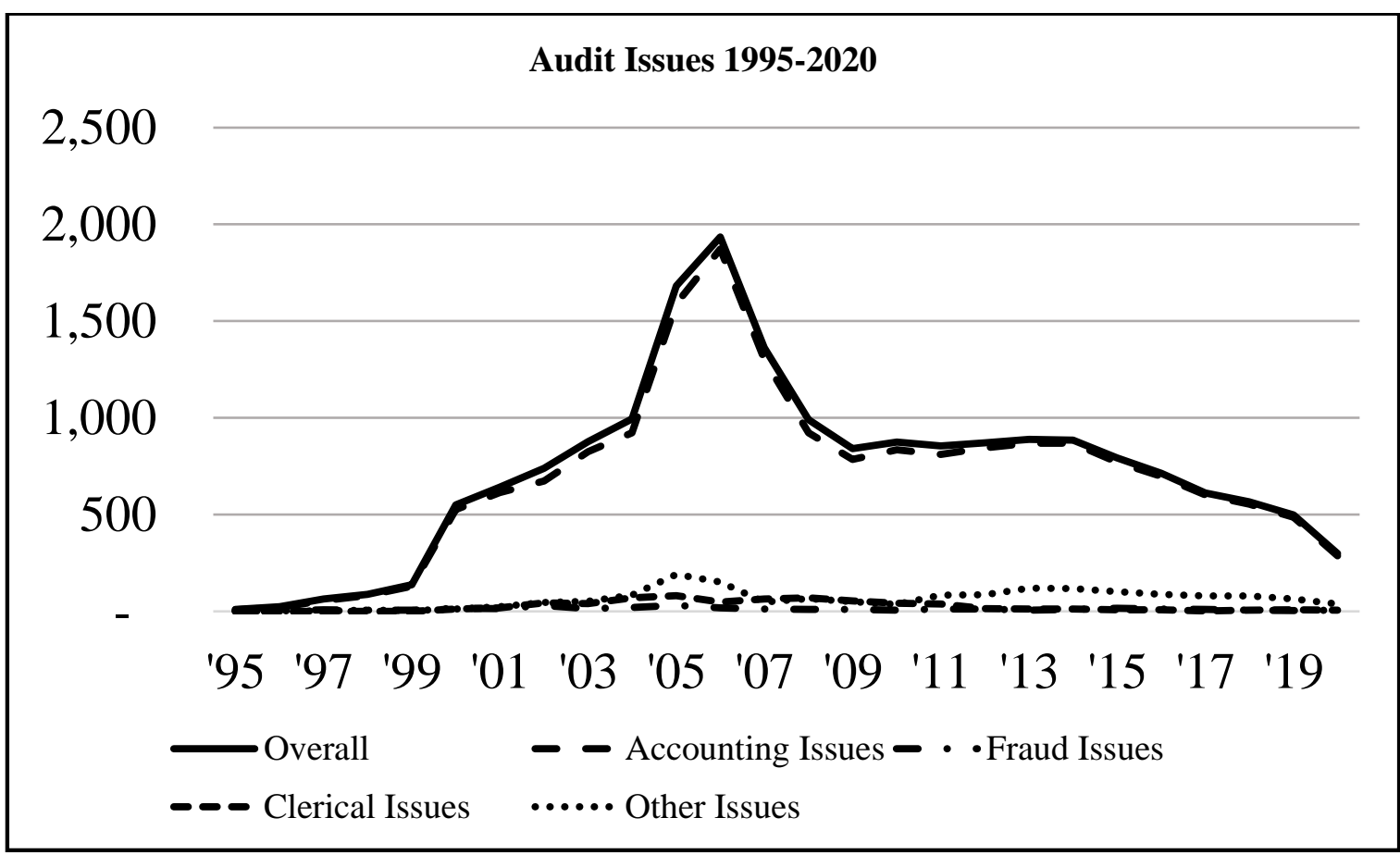

Source: Author created using Audit Analytic data (2021).

\section{Fraud Issues}

The period 1995 to 1999 represents a phase that had less than 10 restatements within each year. In 2000, restatements due to fraud issues jumped to 16, a $129 \%$ increase from 1999. In 2001, the frequency of restatements became stable at 15. With the issuance of the SOX ACT (US, 2002), restatements based on fraud issued increased to 30, representing a 100\% increase. The subsequent years of 2003, 2004 and 2005 denotes years of significant decrease to 14 followed by an increase back to 31 in 2005. During the period of 2006 to 2010, fraud issue restatements noticeably decreased by 39\%, 37\%, 8\%, 9\% and 40\%, respectively. These decreases signal a significant downward shift during this period. The number of restatements spiked in 2011 to a total of 13 representing a 117\% increase from 2010. Restatements stabilized during 2014 through 2017 when restatements based on fraud issues decreased to single digit numbers and remained at the low quantity through 2020.

An interesting point is that after subsequent years of smaller peaks and declines, the volume of restatements declined in 2019 to a level lower than 1997. Overall, fraud issues are insignificant as there were only 312 found over the 25-year period of this study as displayed in TABLE 2 . In relation to other accounting issues' impact on restatements, the fraud issues are consistently low.

\section{Clerical Issues}

No restatements resulting from clerical issues are reported until 2000. Beginning in 2000, clerical issue restatements are first reported with a total of 13 and increase in 2001 of $39 \%$ to 18. In 2002, the clerical issue based financial statement restatements jumped a significant amount to 48. Restatements resulting from clerical issues remained in the double-digit range until the US economic downturn 2014 restoration. From 2015 through 2020, restatements resulting from clerical issues dropped back to and remained within the single digit range. 
Although the financial statement restatements resulting from clerical issues have been consistent over time, they total 667 over the 25-year span of this study as displayed in TABLE 2. Clerical issue trends overall are less than $4 \%$ of the accounting issues' impact on total corporate restatements and as indicated in FIGURE 1 are reflected as a static line in the FIGURE 1.

\section{Other Issues}

No restatements resulting from other issues are reported for the year 1995. Restatements reported for the years of 1996 and 1997 are only three for each of the two years. After 1997, the total restatements resulting from other issues rose steadily to a peak in 2005 and 2006 with restatements totaling 191 and 151 respectively which is consist with the restatement increase for all types of issues.

The 2007 restatements dropped back to a double-digit number until 2013 when the number of restatements resulting from other issuers once again were over 100. The other issue-based restatement remained over 100 until 2016 when they decreased to double-digit numbers.

Although the financial statement restatements resulting from other issues such as disclosures have been consistent over time, they total 1,633 over the 25-year span of this study as displayed in TABLE 2 . Other overall issue trends are less than $10 \%$ of the accounting issues' impact on total corporate restatements and as indicated in FIGURE 1.

To develop a better understanding of the restatement resulting from the audit issues, an analysis is made of the industries contributing to the specific audit issue. With the identification of the industry categories, industries responsible for the restatements are determined and discussed.

\section{INDUSTRY FINANCIAL RESTATEMENTS}

Audit Analytics (2020) classifies the 10,581 companies responsible for restatements with a unique numerical identifier i.e., the SIC Code. The Occupational Safety and Health Administration (OSHA), under the United States Department of Labor, lists a taxonomy of SIC Codes representing 10 industry divisions. The OSHA (2020) definition of the 10 divisions of industry are the following.

1. Agriculture, Forestry and Fishing includes establishments whose primary engagement is in agricultural production, forestry, commercial fishing, hunting, and trapping, and related services.

2. Mining includes establishments whose primary engagement is in metal mining, coal mining, oil and gas extraction, and mining and quarrying of nonmetallic minerals, except fuels.

3. Construction includes establishments whose primary engagement is in building construction dealing with dwellings, office buildings, stores, and related projects; heavy construction dealing with highways, pipelines, communications and powerlines, sewer and water mains, and related projects; specialty construction dealing with painting, electrical, asphalt and concrete, grading highways and runways, and related projects.

4. Manufacturing includes establishments whose primary engagement is in the mechanical or chemical transformation of materials or substances into products, assembling component parts of manufactured products, and blending of materials, such as lubricating oils, plastic resins, or liquors.

5. Transportation, Communication, Electric, Gas and Sanitary Service includes establishments, including all establishments of the U.S. Postal Service, whose primary engagement is in providing passenger and freight transportation, communications services, or electricity, gas, steam, water, or sanitary services to the general public or to other business enterprises.

6. Wholesale Trade includes establishments whose primary engagement is in selling merchandise to retailers; industrial, commercial, institutional, farm, construction contractors, or professional businesses; wholesalers; or acting as an agent or broker in buying or selling merchandise.

7. Retail Traded includes establishments whose primary engagement is in selling merchandise for personal or household consumption and rendering services incidental to the sale of goods. 
8. Finance, Insurance and Real Estate includes establishments whose primary engagement is in depository institutions, non-depository credit institutions, holding companies, and other investments companies; all types of insurance, insurance agents and brokers; owners, lessors, lessees, buyers, sellers, agents, and developers of real estate.

9. Services includes establishments whose primary engagement is in hotels and other types of lodging; personal, business, repair, and amusement services; health, legal, engineering, and other types of professional services; education; members organizations; other types of miscellaneous services.

10. Public Administration establishments whose primary engagement is in executive, legislative, and general government; justice, public order, and safety; public finance, taxation, and monetary policy; administration of human resource programs, environmental quality and housing programs, economic programs; national security and international affairs.

The following discussion includes an examination of the financial restatement issue increases and peaks related to each audit issue category. Frequency of each financial restatement issue in relation to the total number of industry financial restatement issues is discussed. Industry financial restatement issues representing $15 \%$ or more of the total population of financial restatement issues reported per responsible industry for a specific year's increase or peak was determined. Further examination of financial restatement issues identifies which of the reporting problems were consistent across all industry reporting issues. The discussion identifies the general reasons for restatement increases and peaks. By identifying consistent and material financial restatement issues over all industries, determinations can be made as to what significant events specifically link reoccurring restatements over types of industries during the same periods.

\section{Industry Restatements Accounting Issues}

Industry financial restatements during the period of 1995 to 2002 were insignificant. After the SOX Act issuance in 2002, the number began to increase. By 2005, the manufacturing and service industry restatements represent half of the 1591 total 2005 restatements resulting from accounting issues (see TABLE 2). Manufacturing industries restatements totaled 495 (31\%), while service industries issues total 303 restatements (19\%), respectively. Restatement issues across the manufacturing and service industries dealt with acquisitions, mergers, disposals, reorganization accounting issues, debt, quasi-debt, warrants issues, depreciation or amortization errors, property and equipment, intangible or fixed asset impairment, and revenue recognition issues.

The largest number of accounting-based issue restatements over the 25 -year period is 1,873 issued in 2006 (TABLE 2). Manufacturing and services represent 57\% of the total 2006 accounting issue related restatements. Manufacturing industries were responsible for 657 (35\%) of the 2006 accounting issue restatements while service industries issued 419 restatements $(22 \%)$.

The 2006 restatement issues for the manufacturing and service industries dealt with acquisitions, reorganization accounting issues, debt, warrants and equity security issues, deferred stock-based and/or executive compensation issues, expense and general administrative recording issues, intangible or fixed asset impairment, and revenue recognition issues.

The third highest number of accounting-based issue restatements over the 1995 through 2020 period was in 2007 with manufacturing industries issuing 430 (33\%) and service industries issuing 261 (20\%) of the total 1,304 restatements. The basis of the 2007 restatement was comparable to the prior year's causes including acquisitions and reorganizations, debt, equity security issues, deferred stock-based compensation plans, expense recording issues, intangible and fixed asset impairment, and revenue recognition issues.

Following 2007, industry accounting-based issue restatements diminished in tandem with the overall accounting issue-based restatements as illustrated in FIGURE 2. 
FIGURE 2

INDUSTRY RESTATEMENTS ACCOUNTING ISSUES 1995 TO 2020

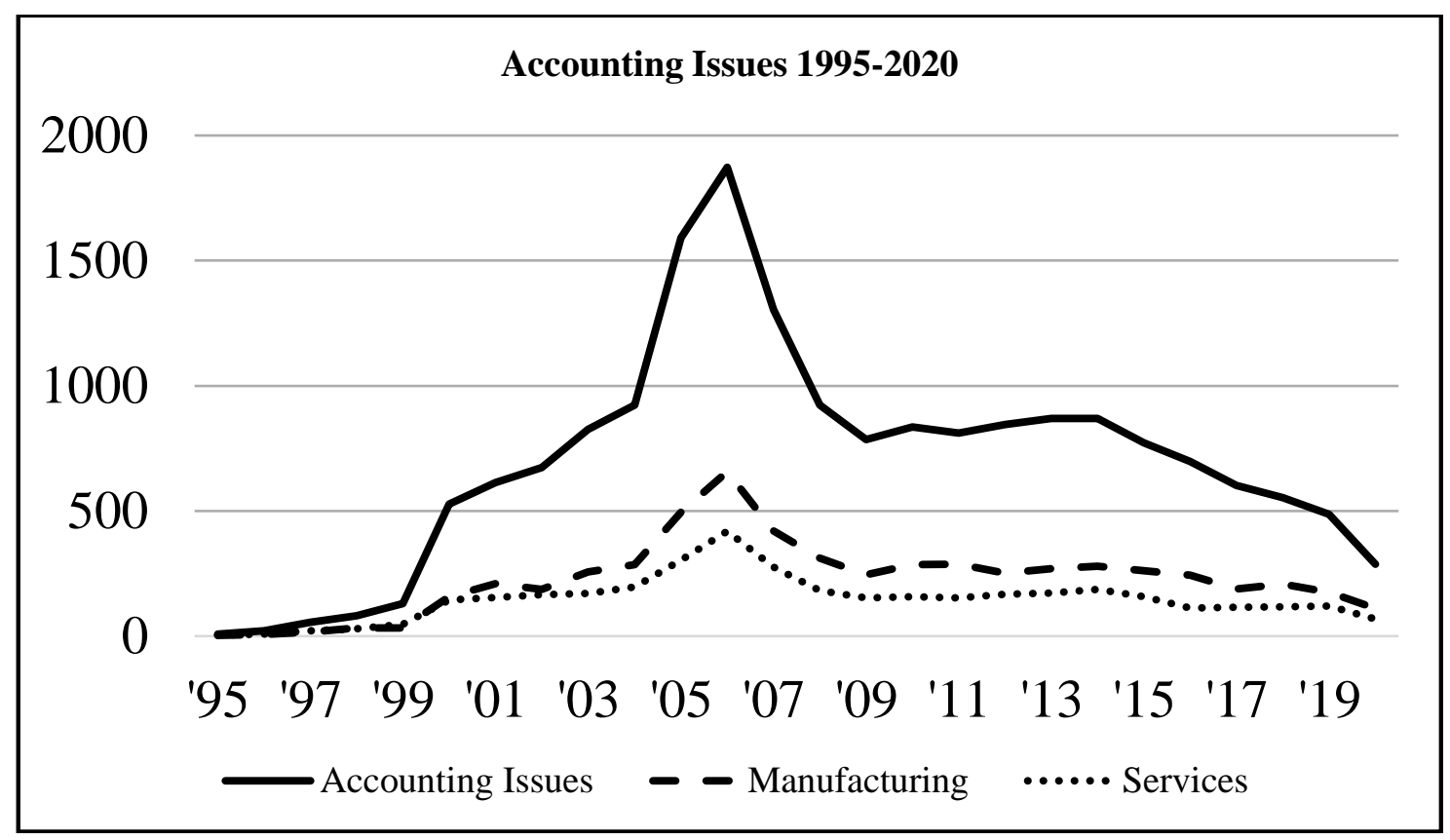

Source: Author created using Audit Analytic data (2021)

\section{Industry Restatements Fraud Issues}

Fraud issue restatements began to increase in 2002 due to manufacturing, transportation and service industries that were responsible for $70 \%$ of the 30 restatements issued in 2002. Of the fraud issue restatements, manufacturing had $6(20 \%)$, transportation $7(23 \%)$ and service 8 (27\%) respectively. Consistent issues across the three industries dealt with intangible or fixed asset impairment and revenue recognition issues.

Revenue recognition continued to be an issue in the following years' fraud issue restatements. In 2005, the fraud issue restatement matched the 2002 overall number of restatements related to fraud. Manufacturing and services were again responsible for the concentration of restatements, contributing 9, (29\%), and $10(33 \%)$ all dealing with revenue recognition issues.

Following 2005, industry fraud issue-based restatements diminished and increased in tandem with the overall fraud issue-based restatements as illustrated in FIGURE 3. 
FIGURE 3

INDUSTRY RESTATEMENTS FRAUD ISSUES 1995 TO 2020

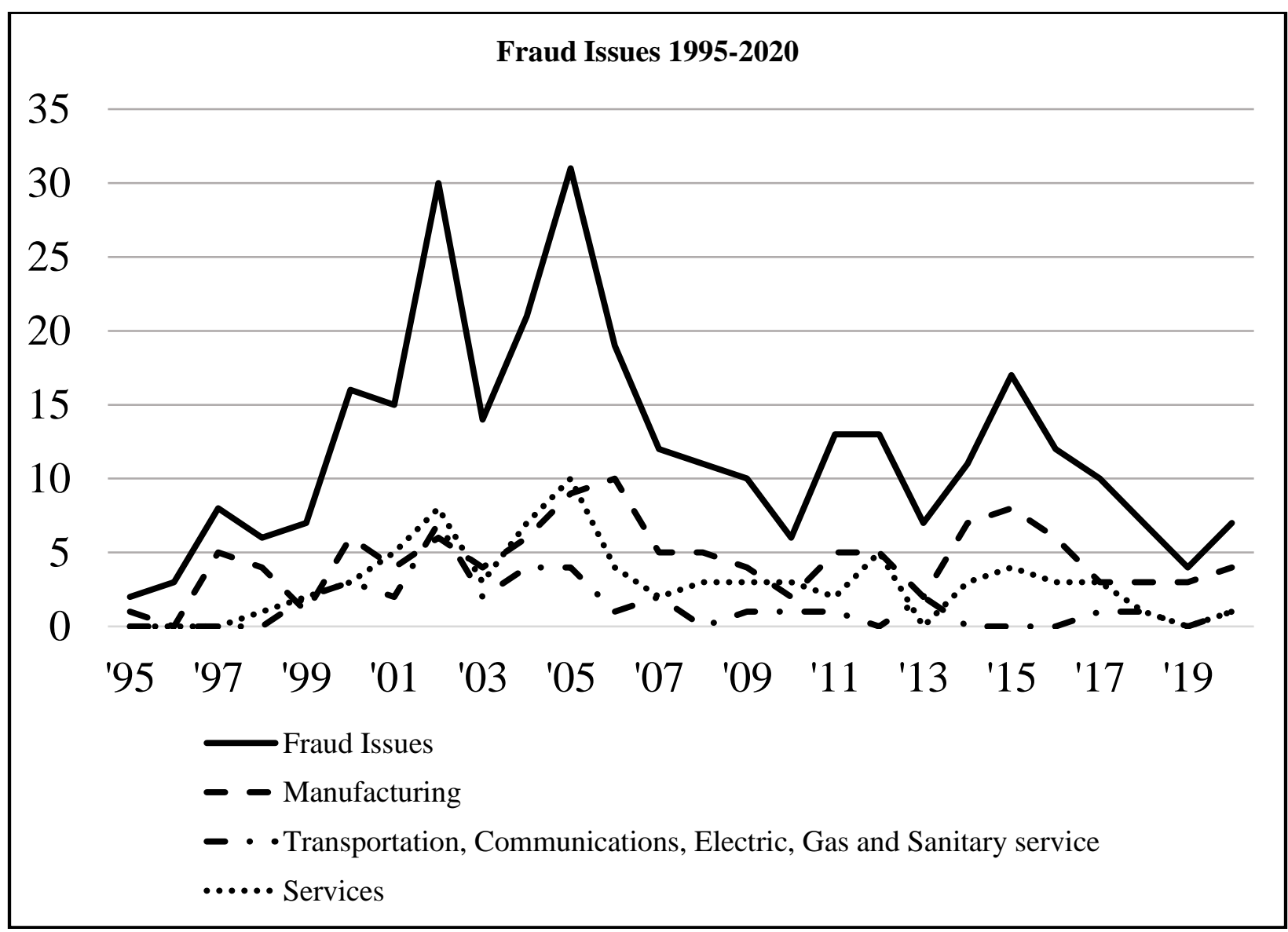

Source: Author created using Audit Analytic data (2021)

\section{Industry Restatements Clerical Issues}

Clerical-based issue restatements were not reported prior to 2000. Over the 15 years between 2000 and 2015 , the number were constant in the two-digit range reducing to a single-digit range from 2015 through 2025.

The first increase in 2004 finds the industry clerical-based issue restatements only totaled $33(48 \%)$ of the 69 total restatements reported. Manufacturing and transportation issued 20 (29\%) and 13 (19\%), respectively. Consistent issues across the two industries dealt with consolidation issues, off-balance sheet transactions, debt, expense recording issues, related party, subsidiary issues, and proforma financial information reporting issues.

In 2005 the clerical-based issued reached their peak over the 25 -year period totaling 81 . Once again, manufacturing and services are responsible for the concentration $(66 \%)$ of restatements, contributing 32 (40\%), and 21 (26\%), respectively. Consistent issues across the two industries dealt with intangible and fixed asset impairments and revenue recognition issues.

Total clerical issue restatements increased again in 2007 with 63 restatements. As in prior years, manufacturing and services are responsible for the concentration of restatements, contributing 24 (38\%) and 12 (19\%), respectively. Consistent issues across the two industries dealt with cash flow statement classification errors, deferred stock-based executive compensation issues, earnings per share, classification of income statement issues, revenue recognition issues, and tax expense/benefit/deferrals. 
In 2008 with the U. S. financial downturn, financial industries join manufacturing and service as industries with clerical issues resulting in $53(76 \%)$ of the 70 clerical-based issue restatements. Consistent issues across the three industries dealt with cash flow statement classification errors, debt, warrants and equity security issues, expense recording issues, and tax expense/benefit/deferral issues.

Following 2008, industry clerical issue-based low two-digit restatements remained constant and decreased to single-digit in 2015 through 2020 as illustrated in FIGURE 4.

\section{FIGURE 4 \\ INDUSTRY RESTATEMENTS CLERICAL ISSUES 1995 TO 2020}

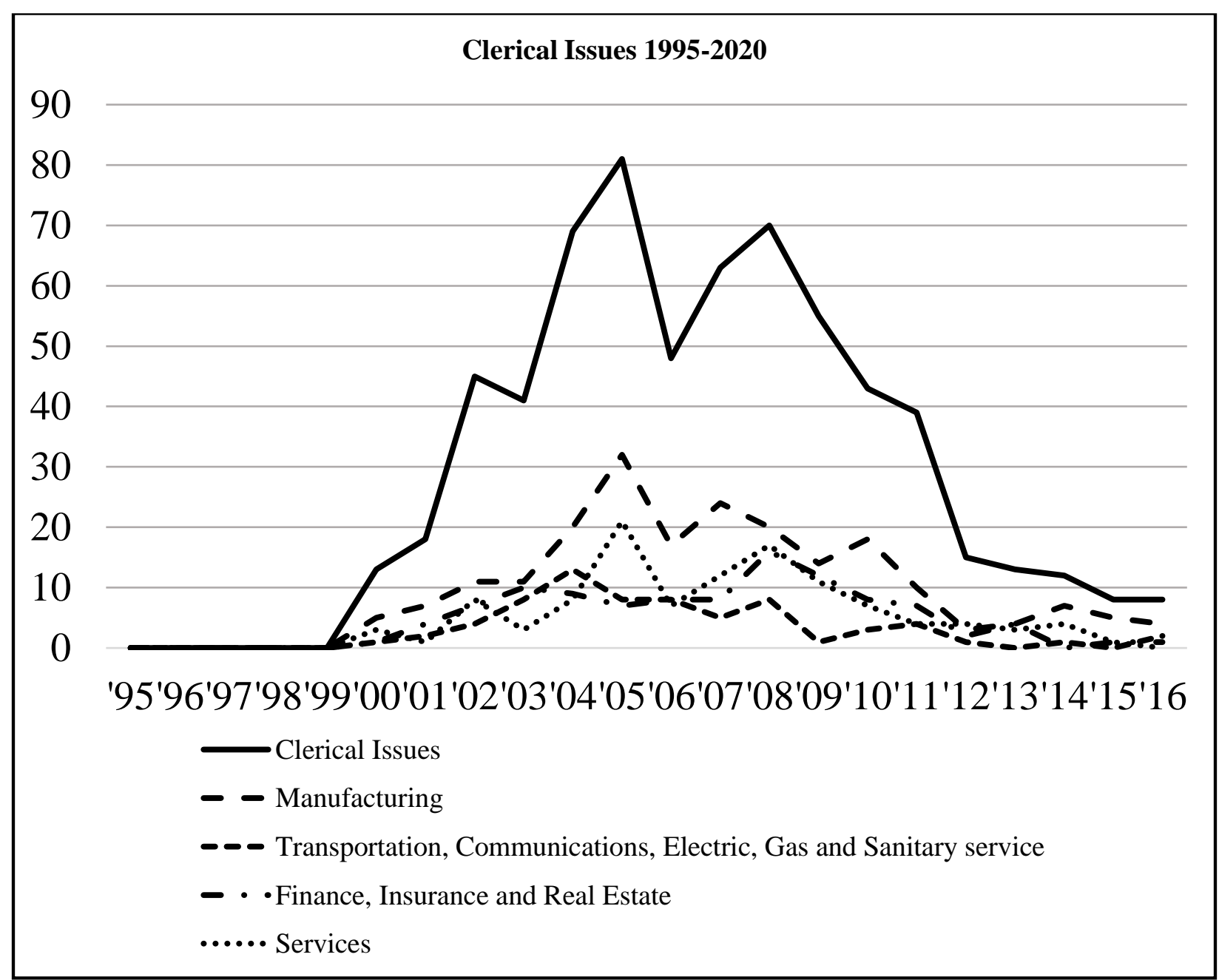

Source: Author created using Audit Analytic data (2021)

\section{Industry Restatements Other Issues}

Total restatements based on all other issues are relatively small until 2005 when 191 restatements were issued. Manufacturing, financial industries, and services were responsible for the concentration of restatements, contributing 65 (34\%); 31 (16\%), and 50 (26)18\% with multiple industries contributing the remaining $24 \%$. Consistent issues across all industries dealt with material weakness and internal control issues. In 2013 through 2015 when industries were recovering from the financial downturn, another significant increase to over 100 restatements resulting from other issues occurred primarily due SOX Act internal control reporting and internal weaknesses. After 2015, restatements with other issues began a gradual decline as detailed in TABLE 2 and FIGURE 5. 
FIGURE 5

INDUSTRY RESTATEMENTS OTHER ISSUES 1995 TO 2020

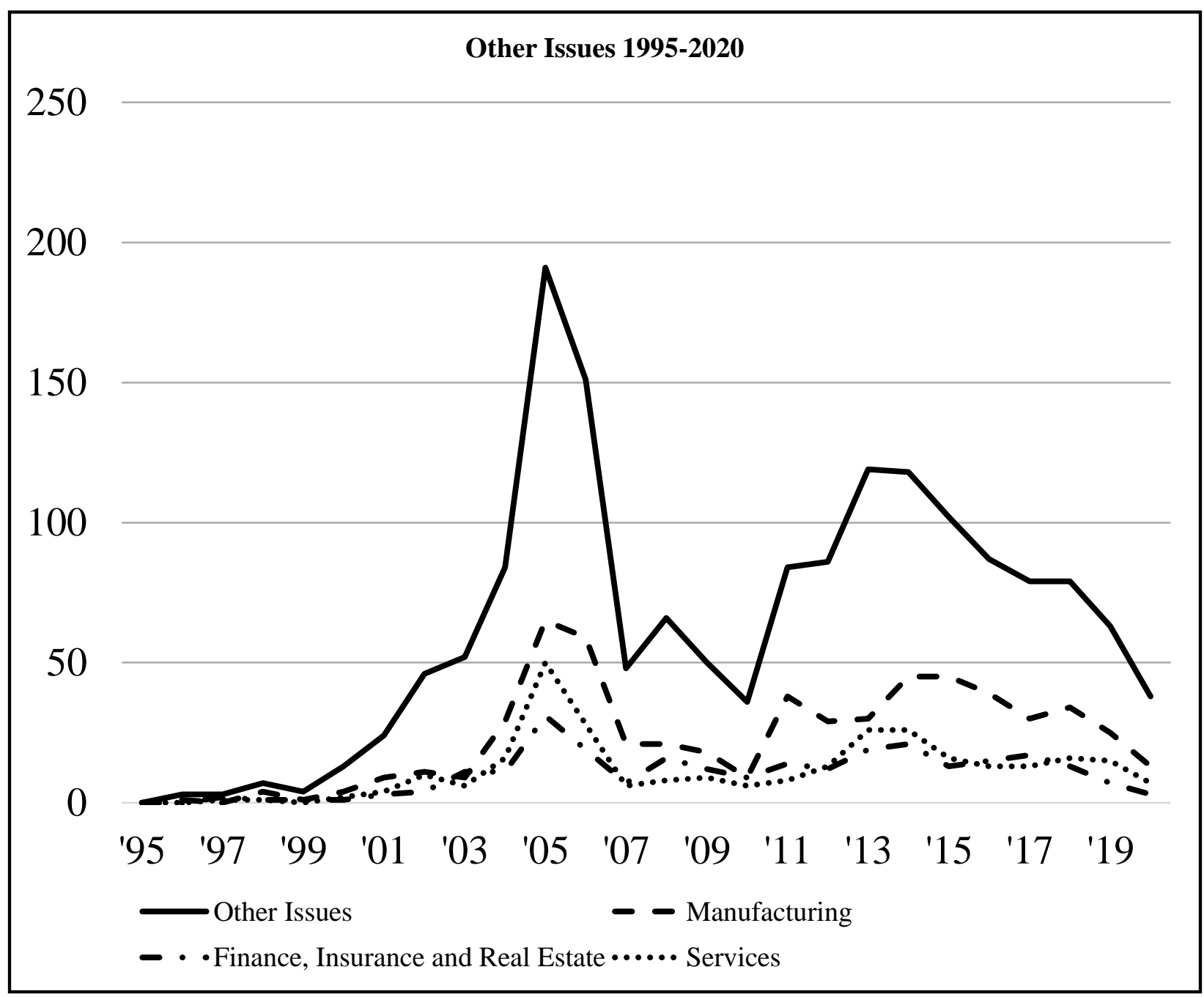

Source: Author created using Audit Analytic data (2021)

\section{DISCUSSION}

Reasons for the various increases and peaks regarding financial restatement issues relating to accounting issues, fraud issues, clerical issues, and other issues can be linked to preexisting and new issuance of Statements of Financial Accounting Standards (SFAS); FASB Interpretations (FIN); Staff Accounting Bulletins (SAB); and Sections of the Sarbanes-Oxley Act of 2002.

Instances of fraud in 2002 can be linked to the lack of regulations and ethical standards within the corporate and auditing environment as much of the fraudulent activity is attributed to the lack of adequate controls designed to monitor management's activities (Ghosh et al., 2010). The issuance of the SOX legislation caused restatements to climb in the following years, as corporate accountants were held to higher reporting standards, auditors were held to high performance, and unethical standards as well as prior period accounting irregularities came to light (Coffee, 2005). Restatements due to intangible or fixed asset impairment issues were attributed to intentional misapplications of new SFAS issued in 2001 including business combination, documenting and recording goodwill, and other intangibles and asset impairment. Early restatements due to revenue recognition issues are linked to violations of SEC Staff Accounting 
Bulletins that provided guidance to public companies regarding methods to properly recognize revenue in 1999 (Srivastava, 2014).

Financial restatements in 2004 stemming from clerical issues and fraud issues are a byproduct of changes in consolidation, variable interest, and off-balance sheet reporting guidance (Callahan et al., 2012). Restatements due to debt, quasi-debt, warrants and equity security issues can be linked to the 2000 new guidance pertaining to the servicing of financial assets and 2003 pension disclosures (Lin et al., 2015). Restatements due to expense (payroll, SGA, other) recording issues can be traced to errors in applying lease reporting guidance and rules to clarify its misapplications (Lin et al., 2015; Turner \& Weirich, 2006). Restatements due to fraud, related party, affiliated, or subsidiary issues can be attributed to violations of old related party disclosure guidance issued in the 1980s (Gordon et al., 2004). The 2004 restatements due to pro forma financial information reporting issues are attributed to violations of SOX internal control guidance (Entwistle et al., 2006). While the increased number of restatements due to fraud and revenue recognition issues are linked to the 2003 Staff Accounting Bulletins (Hermanson et al., 2008).

Many of the 2005 financial restatement issues can be linked to the preexisting guidance and newly issued standards influenced by SOX 2002 legislation. Restatements due to acquisitions, mergers, disposals, reorganization accounting issues are in part due to revised business combination accounting guidance (Turner \& Weirich, 2006) and guidance pertaining to the recognition of costs associated with business combination liquidations (Schipper, 2007). The 2005 restatements due to debt, quasi-debt, warrants \& equity (BCF) security issues can be linked to classification of financial instrument guidance (Lin et al., 2015). Whereas the restatements due to depreciation, depletion or amortization errors can be attributed to the failure to apply share-based compensation guidance (Lin et al., 2015; Turner \& Weirich, 2006). Restatements due to intangible or fixed asset (value/diminution) issues can also be linked to intangible asset and long-lived asset valuation (Cheng, 2003; Fitzsimons \& McCarthy, 2002). Other 2005 restatements due to revenue recognition issues can be attributed to a SEC revised accounting bulletin (Hermanson et al., 2008). While the restatements due to fraud and material weakness can be attributed to the adoption of SOX internal control documentation effective on or after November 2004 (Hermanson et al., 2008). SOX legislation specifically requires that management issue a report detailing the effectiveness of internal controls over financial reporting; the new guidance also requires that external auditors issue a report expressing an opinion on the effectiveness of internal control over financial reporting (Hermanson et al., 2008). Whereas 2005 restatements due to fraud and foreign, related party, affiliated, or subsidiary issues likely result from violations of the recognition of related party relationships (Gordon et al., 2004).

The spike in restatements for 2007 were primarily due to clerical issues that were influenced by SOX legislation in addition to preexisting and newly issued SFAS. Restatements due to cash flow statement classification errors are linked to classification and recognition errors (Alali \& Wang, 2017). Restatements of 2007 financial reports due to deferred, stock-based and/or executive comp issues can be attributed to new recognition of costs as expense rather than a capitalization (Ratliff, 2005). Restatements due to EPS, ratio and classification of income statement issues can be attributed to erroneous financial instrument documentation (Lin et al., 2015), disclosure of earnings per share, and reporting information about capital structure issues (Fleming, 2003). The 2007 restatements due to expense (payroll, SGA, other) recording issues are linked to improper lease-accounting practices relating to violations of preexisting recognition guidance (Turner \& Weirich, 2006). Restatements of 2007 annual financial reports due to revenue recognition issues are linked to SEC accounting bulletins (Hermanson et al., 2008). Restatements due to tax expense, benefits and deferred taxes can be attributed to FASB guidance regarding the accounting for uncertainty in income taxes (Lee \& Swenson, 2010).

The 2008 restatements are related to fewer but similar financial statement issues that were realized in 2007. Restatements were primarily due to clerical issues that were influenced by SOX and preexisting and newly issued SFAS. Restatements in 2008 are also due to cash flow statement classification errors (Alali \& Wang, 2017). Fitzsimons and Mannino (2006) claim 2008 financial statement restatements were related to reporting debt, quasi-debt, warrants and equity security issues. Restatements due to expense (payroll, SGA, other) recording issues can be attributed to improper lease-accounting practices (Turner \& Weirich, 2006). 
Other 2008 restatements due to tax expense, benefits, deferrals, and other issues can be attributed to tax reporting (Lee \& Swenson, 2010).

Since 2008, restatements of annual financial accounting statement have slowly diminished year by year to 2020 when the restatements number less than the year 2000. Although the number of restatements have declined, the justification for the restatements remain comparable to the earlier year. That is, the restatements are the result of inappropriate recognition or incorrect interpretation of new accounting guidance. Fraud and clerical issues continue to be an insignificant cause for a restatement.

Although this study investigates the issues resulting in annual financial report restatements over the past two decades, deeper analysis should be made in the future to understand if consistent financial restatement issues continue to result in reporting restatements in future periods. Or, are future annual financial restatements related to new guidance or specific reasons unique to future processes and accounting issues. For now, with limited scope, only broad generalizations and assertions are appropriate.

\section{CONCLUSION}

The flood gate of sweeping reform such as Sarbanes-Oxley introduced financial reporting reviews to safe-guard the public's wealth and to restore trust in the corporate and public sector. As the nature of the auditor relationship between regulators and corporate management continues, the subject of restatements will persist in being a controversial topic and reoccurring issue. Likewise, as the economic domain becomes more sophisticated with enhanced technology and innovative business processes, regulators continue to design and issue new guidance to assure financial reporting controls that increase the oversight demands of public accounting and reporting. Regardless of whether the economy is booming or in recession, there continues be the need to discover irregularities, if any, in published corporate annual financial reports

\section{REFERENCES}

Alali, F., \& Wang, S. (2017). Characteristics of Financial Restatements and Frauds: An Analysis of Corporate Reporting Quality from 2000-2014. The CPA Journal, 87(11), 32-41.

Audit Analytics. (2020). Adjustment Database [Data set]. Retrieved from https://www.auditanalytics.com.

Callahan, C., Smith, R., \& Spencer, A. (2012). An Examination of the Cost of Capital Implication of FIN 46. The Accounting Review, 87(4), 1105-1134.

Cheng, K. (2003). The Impact of Goodwill on Earnings. The Journal of Corporate Accounting \& Finance, 14(2), 63-67.

Coffee, J. (2005). A Theory of Corporate Scandals: Why the USA and Europe Differ. Oxford Review of Economic Policy, 21(2), 198-211.

Cunningham, L. (2002). The Sarbanes-Oxley Yawn: Heavy Rhetoric, Light Reform (And it Might Just Work). Connecticut Law Review, 36, 915-988.

Entwistle, G., Feltham, G., \& Mbagwu, C. (2006). Financial Reporting Regulation and the Reporting of Pro Forma Earnings. Accounting Horizons, 20(1), 39-55.

Fitzsimons, A., \& Mannino, L. (2006). FASB clarifies an Accounting Alternative for a Financial Instrument with an Embedded Derivative. Commercial Lending Review, 21(3), 37-40.

Fitzsimons, A., \& McCarthy, I. (2002). FASB Issues Accounting Guidance for the Impairment or Disposal of Long-Lived Assets. Commercial Lending Review, 17(2), 44-48.

Fleming, M. (2003). Improving disclosure requirements for restated earnings per share. Journal of Investing, 12(1), 66-70.

Ghosh, A., Marra, A., \& Moon, D. (2010). Corporate Boards, Audit Committees, and Earnings Management: Pre- and Post-SOX Evidence. Journal of Business Finance \& Accounting, 37(9), $1145-1176$.

Gordon, E., Henry, E., \& Palia, H. (2004). Related Party Transactions and Corporate Governance. Advances in Financial Economics, 9, 1-27. 
Hermanson, D., Ivancevich, D., \& Ivancevich, S. (2008). SOX Section 404 Material Weaknesses Related to Revenue Recognition. The CPA Journal, 78(10), 40-45.

IVES Group Inc. (2020). Marketing Intelligence Through Data Analytics. Retrieved from https://www.ivesinc.com

Lee, N., \& Swenson, C. (2010). Shock and Law: Fin 48 Report Card, IFRS, and Beyond. International Journal of Economics and Finance, 2(3), 222-233.

Lin, P., Lee, S., Chen, X., \& Yur-Austin, J. (2015). Highlights of Financial Restatements from 2000 through 2011. Management Accounting Quarterly, 17, 19-32.

Occupational Safety and Health Administration. (2020). Standard Industrial Classification (SIC) Manual. United States Department of Labor. Retrieved from https://www.osha.gov/data/sic-manual

Ratliff, P. (2005). Reporting Employee Stock Option Expenses: Is the Debate Over? The CPA Journal, 75(11), 38-43.

Schipper, K. (2007). Required Disclosures in Financial Reports. The Accounting Review, 82(2), 301-326.

Srivastava, A. (2014). Selling-price estimates in revenue recognition and the usefulness of financial statements. Review of Accounting Studies), 19(2), 661-697.

Turner, L., \& Weirich, T. (2006). A Closer Look at Financial Statement Restatements: Analyzing the Reasons Behind the Trend. The CPA Journal, 76(12), 12-23.

U. S. Securities \& Exchange Commission (SEC). (2020). Financial Reporting Manual. Retrieved from www.SEC.gov

United States. (2002). Sarbanes-Oxley Act of 2002: Conference report (to accompany H. R. 3763). Washington, D.C.:U.S. G.P.O. 